\title{
Aedes aegypti, the dengue fever mosquito in Mexico City. Early invasion and its potential risks
}

\author{
María D. Mejía-Guevara, ${ }^{1}$ Fabián Correa-Morales, ${ }^{2}$ Cassandra González-Acosta, ${ }^{3}$ \\ Eduardo Dávalos-Becerril, ${ }^{2}$ Jorge L. Peralta-Rodríguez, ${ }^{4}$ Andrés Martínez-Gaona, ${ }^{4}$ \\ Mariela Hernández-Nava, ${ }^{4}$ Carlos Ramírez-Huicochea, ${ }^{4}$ Leopoldo Rosas-Trinidad, ${ }^{4}$ \\ Mariana Carmona-Pérez, ${ }^{3}$ Víctor Salazar-Bueyes, ${ }^{2}$ Fernando Tapia-Olarte ${ }^{1}$ and Miguel Moreno-García * \\ ${ }^{1}$ Sub-directorate of Epidemiology Surveillance and Evaluation. Mexico City Health Services, Mexico City; ${ }^{2}$ Centro Nacional de Programas Preventivos \\ y Control de Enfermedades, Mexico City; ${ }^{3}$ Vector-Borne Diseases and Zoonosis Coordination, Morelos Health Services, Morelos; ${ }^{4}$ Entomologic \\ Research and Bioassay Unit, Panchimalco Regional Vector Control Center, Morelos Health Services, Morelos. Mexico
}

\begin{abstract}
Introduction: Mexico City has no endemic presence of Aedes aegypti, and it is therefore free of vector-borne diseases, such as dengue fever, Zika and chikungunya. However, evidence has shown the presence of Aedes aegypti eggs in the city since 2015. Objective: To report the constant and increasing presence of Aedes aegypti eggs in Mexico City from 2015 to 2018. Methods: Surveillance was carried out using ovitraps. Eggs were counted and hatched in order to determine the species. Results: From 2015 to 2018, 378 organisms were identified as Ae. aegypti. In total, 76 Aedes aegypti-positive ovitraps were collected at 50 different places in 11 boroughs of the city. Northeastern Mexico City was the area with the highest number of positive traps. Conclusions: The results may be indicating a period of early colonization and the probable existence of cryptic colonies of the mosquito; Mexico City could be at risk of experiencing vector-borne epidemics.
\end{abstract}

KEY WORDS: Aedes aegypti. Mexico City. Vector-borne diseases. Mosquitoes Entomological surveillance.

\section{El mosquito del dengue en la Ciudad de México. Invasión incipiente de Aedes aegypti y sus potenciales riesgos}

\section{Resumen}

Introducción: La Ciudad de México no tiene presencia endémica de Aedes aegypti, por lo que está libre de enfermedades transmitidas por vector como dengue, Zika y chikunguña. Sin embargo, existe evidencia de la presencia de huevecillos en la urbe desde 2015. Objetivo: Reportar la presencia constante y en aumento de huevecillos de Aedes aegypti en la Ciudad de México de 2015 a 2018. Método: Se realizó vigilancia a través de ovitrampas; se contabilizaron y eclosionaron hueveciIlos para determinar la especie. Resultados: De 2015 a 2018 fueron identificados 378 organismos como Aedes aegypti. En total fueron colectadas 76 ovitrampas positivas a Aedes aegypti en 50 sitios distintos de 11 alcaldías. El noreste de la Ciudad de México fue el área con mayor positividad. Conclusiones: Los resultados pueden estar indicando un periodo de colonización incipiente y la probable la existencia de colonias crípticas del mosquito, por lo que la Ciudad de México podría estar en riesgo de presentar epidemias de enfermedades transmitidas por vector.

PALABRAS CLAVE: Aedes aegypti. Ciudad de México. Enfermedades transmitidas por vector. Mosquitos. Vigilancia entomológica.

\footnotetext{
Correspondence: 


\section{Introduction}

The Aedes aegypti mosquito (order: Diptera; family: Culicidae; subgenus Stegomyia), originally described as Culex aegypti by Carl Linnaeus in 1792, is the main vector for the transmission of arboviruses (contraction of "arthropod-borne viruses") such as those that cause yellow fever, dengue, Zika and chikungunya. The diseases caused by these arboviruses are called vector-borne diseases (VBD). Currently, 30 states of Mexico report cases of endemic VBDs, with Tlaxcala and Mexico City (CDMX - Ciudad de México) being the only VBD-free states.

CDMX is 2,240 $\mathrm{m}$ above sea level, and its annual average temperature ranges from $-2{ }^{\circ} \mathrm{C}$ to $28{ }^{\circ} \mathrm{C}$. It has temperate-sub-humid, semi-cold-sub-humid-humid, semi-dry temperate climates, as well as seasonal rains in the summer, with an average annual rainfall of $720 \mathrm{~mm} \cdot{ }^{1,2}$ Owing to these geographical and climatic characteristics, it constituted an area with little probability for the establishment of Aedes aegypti, a species adapted to tropical and subtropical climates. However, recent evidence shows an intermittent presence of the mosquito in the city. 3,4

There are causative factors for Aedes aegypti introduction and colonization. Continuous urbanization (legal and illegal), housing poor conditions and overcrowding, insufficient access to water and sewerage and deficient waste management; climate change and water and air temperature increase in urban areas, ${ }^{5,6}$ as well as mobility of individuals from places with permanent mosquito presence, can induce dispersal of the vector and the virus. ${ }^{7], 8}$ The interaction of these factors puts CDMX at risk of becoming an area where mosquitoes (and the arboviruses they transmit) can become established.

Given that CDMX is surrounded by states with $A e$ des aegypti permanent presence and endemic VBDs (State of Mexico and Morelos), and since it has high human and foreign transportation mobility, as well as atmospheric temperature increase (Fig. 1), since 2009 was the use of ovitraps established for mosquito monitoring. Ovitraps are dark containers that are lined inside with an oviposition substrate and that are filled with water; ${ }^{9}$ they simulate the places where the mosquito lays its eggs and constitute a tool for the monitoring of Aedes aegypti and other mosquitoes. ${ }^{10-12]}$ The first registration of Aedes aegypti eggs in CDMX was carried out in $2015 ;{ }^{3}$ ever since, a constant increase in the number of ovitraps with mosquito eggs has been detected. In this article, the presence of the mosquito detected using ovitraps from 2015 to 2018 is reported, and the potential establishment of Aedes aegypti in CDMX, as well as the possible risk it represents for public health, are discussed.

\section{Method}

Collections were carried out according to the $\mathrm{Na}$ tional Center for Preventive Programs and Disease Control Methodological Guidelines. ${ }^{9}$ The ovitraps consisted of 1-L black plastic containers. As oviposition substrates, $12 \mathrm{~cm}$ wide by $35 \mathrm{~cm}$ long nonwoven (Pellon) fabric (F-1600) sheets were used. The inner surface of the ovitrap was lined with the substrate and filled with water, without reaching the upper edge in order to leave 2-3 cm of the sheets exposed (which is the area where the females lay their eggs), and placed on shady places at less than $1.5-\mathrm{m}$ height. The ovitraps were checked every seven days and the sheets with eggs were removed, onto which the eggs found in the water or at the bottom of the ovitraps were deposited, which were washed, lined with new sheets, replenished with clean water and placed back at the same place.

The nonwoven sheets were submitted to the Panchimalco Regional Center for Vector Control Entomological Research and Bioassay Unit, in Morelos, where the count and hatching of the eggs, as well taxonomic determination of the organisms, were carried out. For hatching, the nonwoven sheets were submerged in water in plastic trays containing $1 \mathrm{~L}$. The hatched larvae were fed rat kibble. The emerged adults were placed in plastic mesh cages and fed ad libitum with a sugar solution. Rearing temperature was $29 \pm 2{ }^{\circ} \mathrm{C}$, with $60-70 \%$ relative humidity and natural light-dark periods. The larvae were taxonomically characterized during the third and fourth stages of development. For larvae and adult specimens stratification, Ibáñez-Bernal and Martínez-Campo ${ }^{13}$ and Darsie and Ward $^{14}$ taxonomic keys were used.

The ovitraps were placed at non-residential public areas such as gardens, public squares and parks, nature reserves within the urban area, avenues and traffic islands. External areas with free access to health centers, schools, churches, markets, sports or recreation units, community centers, foreign bus stations and piers (at Xochimilco) were also included. Annually, 2,240 ovitraps were placed, except in 2015, when 1,440 were used, with all 16 CDMX districts being covered. 

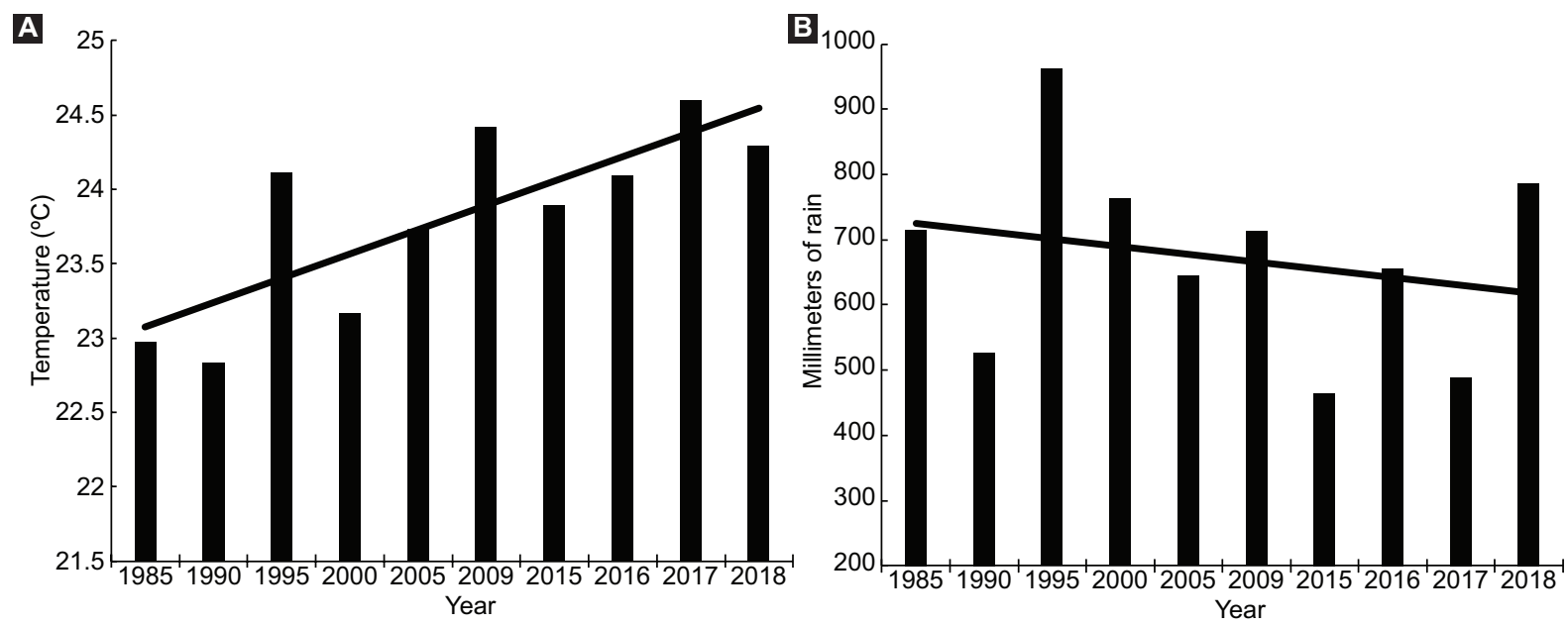

Figure 1. A) Mexico City average annual maximum temperature and B) annual historical precipitation (mm). Source: https://smn.cna.gob.mx/es/ climatologia/temperaturas-y-lluvias/resumenes-mensuales-de-temperaturas-y-lluvias

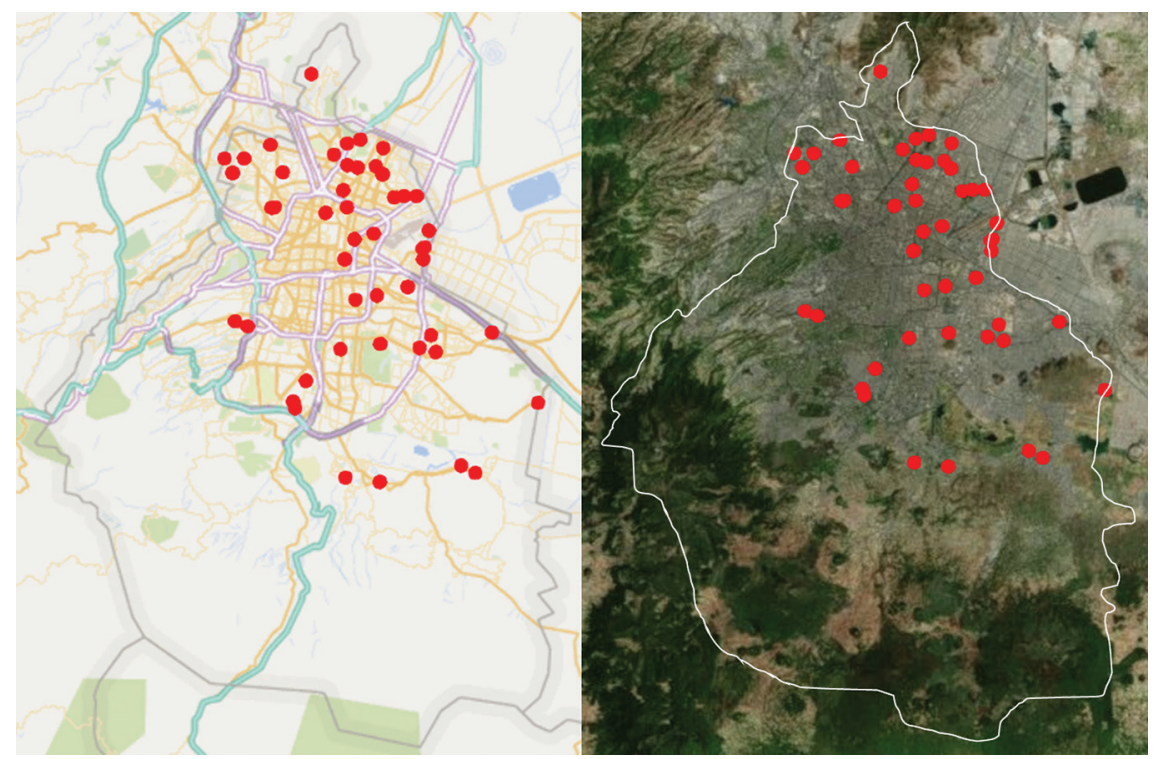

Figure 2. Location of the sites with Aedes aegypti-positive ovitraps collected in Mexico City (urban and satellite map view).

\section{Results}

From the collections carried out between 2015 and 2018, 1,531 ovitraps with eggs were detected, collected at 358 different places. Total number of eggs was 48,477 , out of which 16,171 were hatched; 378 were Aedes aegypti, which represented $0.77 \%$ of hatching success. In total, 76 Aedes aegypti-positive ovitraps were collected at 50 different places in 11 districts (Fig 2. and Table 1). The highest number of larvae was collected in September (rainy season); however, positivity was detected from May to November (Table 1).
Sixteen sites were positive on more than one occasion, and most records occurred in north, northeast and center CDMX (Table 1 and Fig. 3A). Several places were areas with a high attendance of both local and foreign people, as well as tourist areas (e.g., San Juan de Aragón Park and Zoo, Tepeyac Reserve, TAPO bus station and Xochimilco Zacapa Pier). In some cases, positivity was repeated between years, and in others, positivity was detected at different collections within the same year (Table 1).

Positive ovitraps started being identified in the Northeast (2015, 2016 and first semester of 2017), which is an area that has a temperature that ranges 
Mejía-Guevara MD, et al.: Aedes aegypti in Mexico City

Table 1. Places in Mexico City where Aedes aegypti was collected using ovitraps between 2015 and 2018

\begin{tabular}{|c|c|c|c|c|c|c|}
\hline Year & District & Site & Latitude & Longitude & Month & No. of larvae \\
\hline \multirow[t]{2}{*}{2015} & Azcapotzalco & Suburban train (Pantaco) & 19.479908 & -99.168761 & September & 14 \\
\hline & Gustavo A. Madero & Casa del Peregrino & 19.483314 & -99.109786 & September & 4 \\
\hline \multirow[t]{3}{*}{2016} & Venustiano Carranza & Alameda Oriente & 19.436358 & -99.053873 & September & 1 \\
\hline & Venustiano Carranza & CONALEP Airport & 19.424043 & -99.057283 & - & 1 \\
\hline & Venustiano Carranza & TAPO & 19.42989 & -99.112319 & - & 1 \\
\hline \multirow[t]{32}{*}{2017} & Álvaro Obregón & Mayan Baseball League & 19.364826 & -99.196399 & September & 14 \\
\hline & Álvaro Obregón & Valentín G. Farías Park & 19.368711 & -99.206424 & September & 1 \\
\hline & Azcapotzalco & Alameda Norte & 19.500219 & -99.178502 & September & 1 \\
\hline & Azcapotzalco & Renovación Nacional Sport Center & 19.490113 & -99.214643 & September & 2 \\
\hline & Azcapotzalco & Margarita Maza de Juárez Garden & 19.490282 & -99.199102 & November & 1 \\
\hline & Azcapotzalco & Chilapillas Park & 19.479363 & -99.208156 & August & 1 \\
\hline & Coyoacán & Santa Úrsula Sport Center & 19.308975 & -99.160651 & October & 8 \\
\hline & Coyoacán & Santa Úrsula Sport Center & 19.308975 & -99.160651 & September & 2 \\
\hline & Coyoacán & Las Montañas Park & 19.347868 & -99.123349 & November & 2 \\
\hline & Coyoacán & Las Montañas Park & 19.347868 & -99.123349 & October & 6 \\
\hline & Coyoacán & Santa Úrsula Park & 19.303734 & -99.159131 & June & 1 \\
\hline & Cuauhtémoc & Santiago Garden & 19.449623 & -99.135017 & September & 1 \\
\hline & Gustavo A. Madero & Basilica of Guadalupe & 19.485171 & -99.117862 & October & 1 \\
\hline & Gustavo A. Madero & San Juan de Aragón Park & 19.462061 & -99.073349 & September & 1 \\
\hline & Gustavo A. Madero & Carmen Serdán Sport Center & 19.553124 & -99.146329 & July & 1 \\
\hline & Gustavo A. Madero & Heberto Castillo Sport Center & 19.497863 & -99.089899 & June & 8 \\
\hline & Gustavo A. Madero & Luiggy Sport Center & 19.484424 & -99.095655 & August & 1 \\
\hline & Gustavo A. Madero & Luiggy Sport Center & 19.484424 & -99.095655 & July & 4 \\
\hline & Gustavo A. Madero & Luiggy Sport Center & 19.484424 & -99.095655 & September & 2 \\
\hline & Gustavo A. Madero & Miguel Alemán Sport Center & 19.493173 & -99.128598 & September & 8 \\
\hline & Gustavo A. Madero & North Corpus Christi Park & 19.46648 & -99.121144 & August & 2 \\
\hline & Gustavo A. Madero & North Corpus Christi Park & 19.46648 & -99.121144 & July & 1 \\
\hline & Gustavo A. Madero & Justicia Social Recreation Park & 19.478533 & -99.090386 & August & 4 \\
\hline & Gustavo A. Madero & Justicia Social Recreation Park & 19.478533 & -99.090386 & August & 1 \\
\hline & Gustavo A. Madero & Justicia Social Recreation Park & 19.478533 & -99.090386 & November & 5 \\
\hline & Gustavo A. Madero & Justicia Social Recreation Park & 19.478533 & -99.090386 & September & 2 \\
\hline & Gustavo A. Madero & Justicia Social Recreation Park & 19.478533 & -99.090386 & September & 1 \\
\hline & Gustavo A. Madero & Rancho Grande la Villa & 19.501382 & -99.118285 & July & 7 \\
\hline & Gustavo A. Madero & Tepeyac Reserve & 19.504375 & -99.107777 & July & 3 \\
\hline & Gustavo A. Madero & Tepeyac Reserve & 19.504375 & -99.107777 & June & 2 \\
\hline & Gustavo A. Madero & Tepeyac Reserve & 19.504375 & -99.107777 & November & 21 \\
\hline & & & & & & (Continues) \\
\hline
\end{tabular}


Gaceta Médica de México. 2020;156

Table 1. Places in Mexico City where Aedes aegypti was collected using ovitraps between 2015 and 2018 (Continued)

\begin{tabular}{|c|c|c|c|c|c|c|}
\hline Year & District & Site & Latitude & Longitude & Month & No. of larvae \\
\hline & Gustavo A. Madero & Tepeyac Reserve & 19.504375 & -99.107777 & November & 5 \\
\hline & Gustavo A. Madero & Tepeyac Reserve & 19.504375 & -99.107777 & October & 7 \\
\hline & Gustavo A. Madero & San Juan de Aragón Zoo & 19.461268 & -99.081155 & November & 1 \\
\hline & Gustavo A. Madero & San Juan de Aragón Zoo & 19.461268 & -99.081155 & September & 10 \\
\hline & Iztacalco & Dr. Manuel Pesqueira TIII Health Center & 19.394339 & -99.070505 & August & 1 \\
\hline & Iztacalco & Metro Sport Center & 19.387966 & -99.094784 & September & 2 \\
\hline & Iztacalco & El Foro Park & 19.3848 & -99.111596 & July & 1 \\
\hline & Iztapalapa & Salvador Allende Swimming Pool & 19.358232 & -99.052353 & August & 1 \\
\hline & Iztapalapa & Antonio Gómez Rodríguez Library & 19.348838 & -99.061293 & July & 1 \\
\hline & Iztapalapa & Villa Estrella Social Center & 19.351701 & -99.092109 & October & 102 \\
\hline & Iztapalapa & Mexican Sport-Athletic Center & 19.374861 & -99.063031 & September & 1 \\
\hline & Iztapalapa & Santa Cruz Meyehualco Sport Center & 19.345768 & -99.048541 & July & 2 \\
\hline & Iztapalapa & Santa Cruz Meyehualco Sport Center & 19.345768 & -99.048541 & September & 1 \\
\hline & Iztapalapa & Francisco J. Mujica Garden & 19.349013 & -99.061294 & September & 10 \\
\hline & Miguel Hidalgo & CECYT 9 & 19.453899 & -99.175013 & October & 1 \\
\hline & Miguel Hidalgo & CECYT 9 & 19.453899 & -99.175013 & September & 1 \\
\hline & Miguel Hidalgo & Cañitas Garden & 19.45346 & -99.177568 & July & 4 \\
\hline & Tláhuac & Santa Catarina Health Center & 19.307826 & -98.968109 & July & 2 \\
\hline & Venustiano Carranza & Venustiano Carranza Conalep II & 19.422892 & -99.05879 & September & 1 \\
\hline & Venustiano Carranza & Lázaro Cárdenas Sport Center & 19.414801 & -99.119973 & July & 1 \\
\hline & Venustiano Carranza & Lázaro Cárdenas Sport Center & 19.415124 & -99.11997 & November & 22 \\
\hline & Venustiano Carranza & Lázaro Cárdenas Sport Center & 19.414801 & -99.119973 & October & 4 \\
\hline & Venustiano Carranza & Moctezuma Sport Center & 19.434247 & -99.097297 & October & 3 \\
\hline & Venustiano Carranza & Plutarco Elías Calles Sport Center & 19.453841 & -99.118303 & July & 26 \\
\hline & Venustiano Carranza & TAPO & 19.42989 & -99.112319 & June & 15 \\
\hline & Xochimilco & Tulyehualco Cultural Center & 19.255422 & -99.017332 & August & 1 \\
\hline & Xochimilco & Faculty of Arts and Design & 19.251917 & -99.11946 & September & 1 \\
\hline \multirow[t]{9}{*}{2018} & Coyoacán & Huayamilpas Park & 19.324223 & -99.150507 & September & 2 \\
\hline & Gustavo A. Madero & San Juan de Aragón Park & 19.462061 & -99.073349 & July & 1 \\
\hline & Gustavo A. Madero & Lienzo Charro de Aragón & 19.462163 & -99.063339 & July & 1 \\
\hline & Gustavo A. Madero & Tepeyac Reserve & 19.504375 & -99.107777 & July & 1 \\
\hline & Gustavo A. Madero & San Juan de Aragón Zoo & 19.461268 & -99.081155 & May & 1 \\
\hline & Iztacalco & Pantitlán Park & 19.4151 & -99.058379 & July & 1 \\
\hline & Iztapalapa & Salvador Allende Swimming Pool & 19.358232 & -99.052353 & August & 1 \\
\hline & Iztapalapa & Salvador Allende Swimming Pool & 19.358232 & -99.052353 & July & 1 \\
\hline & Iztapalapa & Villa Estrella Social Center & 19.351701 & -99.092109 & September & 1 \\
\hline & & & & & & (Contil \\
\hline
\end{tabular}


Table 1. Places in Mexico City where Aedes aegypti was collected using ovitraps between 2015 and 2018 (Continued)

\begin{tabular}{|c|c|c|c|c|c|c|}
\hline Year & District & Site & Latitude & Longitude & Month & No. of larvae \\
\hline & Iztapalapa & Santa Martha Sport Club & 19.360389 & -99.00439 & September & 1 \\
\hline & Xochimilco & Tulyehualco Cultural Center & 19.255422 & -99.017332 & September & 1 \\
\hline & Xochimilco & $\begin{array}{l}\text { Acuexcomatl Environmental Education } \\
\text { Center }\end{array}$ & 19.260958 & -99.028621 & July & 1 \\
\hline & Xochimilco & Zacapa Pier & 19.248801 & -99.092481 & September & 1 \\
\hline & Xochimilco & Zacapa Pier & 19.248801 & -99.092481 & September & 1 \\
\hline
\end{tabular}

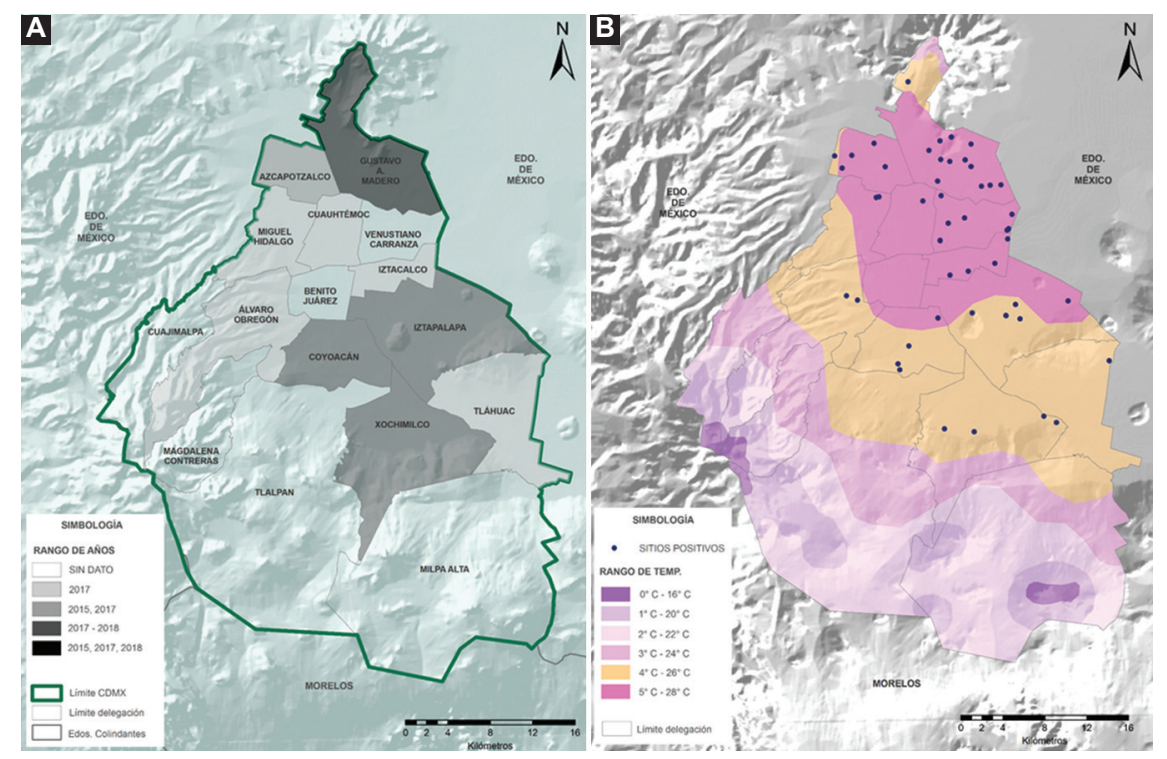

Figure 3. A) Districts with Aedes aegypti-positive ovitraps. The district where positive ovitraps were recurrently observed was Gustavo A. Madero (2015, 2017, 2018), followed by Azcapotzalco, Coyoacán, Iztacalco, Venustiano Carranza and Xochimilco, with two years of positive collections. The district with the highest positivity was Gustavo A. Madero, followed by Xochimilco, Venustiano Carranza and Iztapalapa. B) CDMX temperature ranges with positive ovitraps location during the 2015-2018 period.

between 5 and $28^{\circ} \mathrm{C}$, the highest in the city (Fig. 3B), and a temperate, sub-humid (lower humidity)/semi-dry temperate climate. However, for the second semester of 2017 , the distribution range broadened and reached areas with a temperature ranging from 4 to $24{ }^{\circ} \mathrm{C}$ (temperate, sub-humid climate with intermediate humidity). For 2018, presence of the mosquito was recorded again in these areas (Fig. 3B and 4).

\section{Discussion}

Given that that in 2015 only two Aedes aegypti-positive ovitraps were recorded in places with high human mobility, it was considered to be an accidental introduction. However, the number of positive ovitraps did increase in the ensuing 3 years, which leads to suppose that this finding was not solely due to accidental transport. The lack of larvae or adult specimens collection, coupled with the low proportion of eggs found and hatched, indicates that there are still no Aedes aegypti established populations, although CDMX is in a period of early colonization.

The recurrent presence of positive ovitraps at the same collection site might indicate the possibility of the existence of intermittent cryptic colonies of the mosquito. Aedes aegypti has domestic habits; ${ }^{15,16}$ females tend to oviposit in tanks, barrels and sinks that are kept with water for domestic use (usually due to an inadequate running water network). ${ }^{17}$ During the rainy season, tires, cans, buckets, flowerpots, or any 


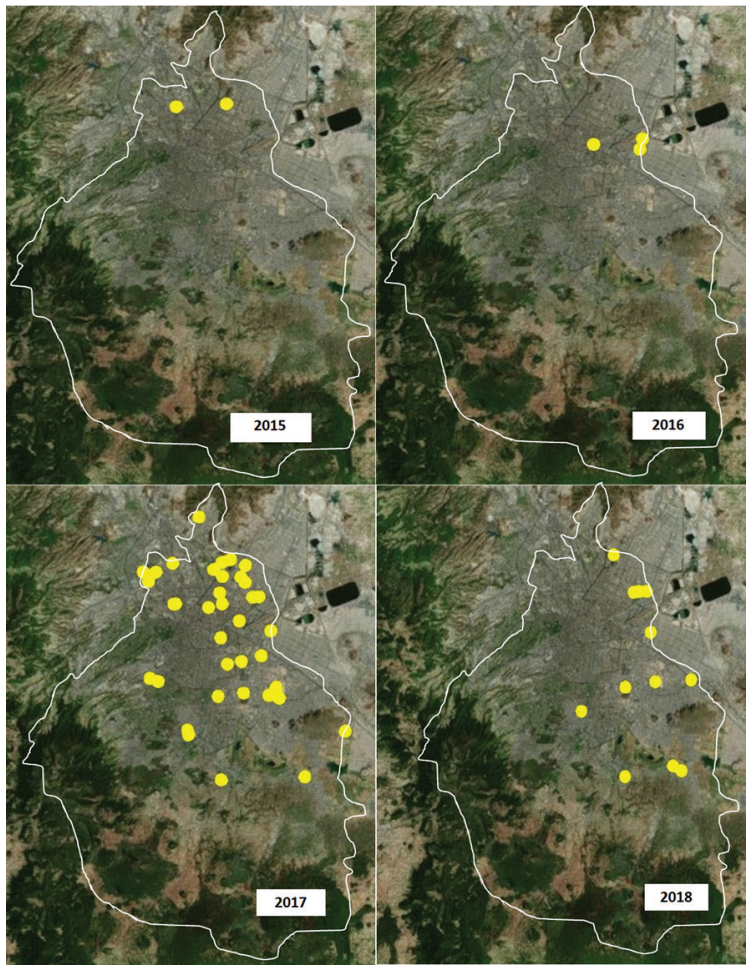

Figure 4. Chronology of the presence of Aedes aegypti-positive ovitraps in Mexico City's urban areas. 2017 was the year with the highest number of positive ovitraps.

container that can accumulate clean water, become ideal places for oviposition inside or outside the households. ${ }^{17}$ However, in the absence of places for oviposition in dry season, females can use alternate sites to deposit their eggs, such as water from water capture boxes, drainage sewers and PVC pipes in underground parking lots. ${ }^{18-22}$ These places tend to maintain a stable, warm temperature in shady areas with low evaporation, ${ }^{22}$ which makes them suitable for harboring mosquito colonies. In addition, these are spaces where observing the presence larvae or pupae is difficult, and thus become risk sites for CDMX.

An important factor to explain the increase in the distribution range of the mosquito is worldwide temperature increase. ${ }^{23,24}$ In Colombia and Bolivia, the mosquito has been found at 2,302 $\mathrm{m}$ and 2,550 $\mathrm{m}$ above sea level, respectively. ${ }^{25.26}$ In Mexico, the mosquito had previously been found at an altitude of 2,133 $\mathrm{m} .{ }^{27}$ Presence at these altitudes may be associated with a temperature increase. The same could be occurring in CDMX, the temperature of which has increased in recent decades. Temperature change makes for the weather to no longer be a barrier to the spread of the mosquito.
The results indicate higher positivity in the warmest areas of the city (northeast), which concentrate the highest population load, lack regular and adequate drinking water supply, and where there is a high risk of floods during the rainy season. ${ }^{28}$ Furthermore, irregular human settlements (which lack public services) are also common in these areas. ${ }^{29}$ In addition to this, people lack the habit of discarding things (i.e., collection and disposal of expendable containers) in patios, around houses or residential areas, thus contributing to the generation of temporary breeding sites.

CDMX is at risk of experiencing VBDs, which can be minimized by adequate surveillance implementation, social participation for creating awareness and diffusing the knowledge on VBDs, the mosquito and control methods; as well as health personnel training in order for them to know and handle the clinical practice guidelines for patient care. ${ }^{30}$ By applying these strategies, CDMX will be able to monitor, limit and control Aedes aegypti populations and associated VBDs.

\section{Ethical disclosures}

Given that no experimentation with human or animal subjects was carried out for the conduction of this study, no specific authorizations were required by the authors' affiliation institutions. Collection locations are not on private property. The field studies did not involve endangered or protected species. The Panchimalco Regional Center for Vector Control Entomological Research and Bioassay Unit is certified by the National Center for Preventive Programs and Disease Control for the breeding and maintenance of mosquito colonies.

\section{Acknowledgements}

We thank the personnel of the vector area of the Ministry of Health of Mexico City for their assistance in the field work.

\section{Conflict of interests}

The authors declare that they have no conflicts of interest.

\section{Funding}

The authors did not receive any sponsoring for carrying out this article. 


\section{Ethical disclosures}

Protection of human and animal subjects. The authors declare that no experiments were performed on humans or animals for this investigation.

Confidentiality of data. The authors declare that no patient data appear in this article.

Right to privacy and informed consent. The authors declare that no patient data appear in this article.

\section{References}

1. Instituto Nacional de Estadística y Geografía [Internet]. Mexico: Anuario estadístico y geográfico del Distrito Federal; 2017.

2. Secretaría del Medio Ambiente y Recursos Naturales [Internet]. Mexico: Precipitación media histórica por entidad federativa; 2019.

3. Kuri-Morales P, Correa-Morales F, González-Acosta C Sánchez-Tejeda G, Dávalos-Becerril E, Juárez-Franco MF, et al. Firs report of Stegomyia aegypti (= Aedes aegypti) in Mexico City, Mexico. Med Vet Entomol. 2017;31:240-242.

4. Dávalos-Becerril E, Correa-Morales F, González-Acosta C Santos-Luna R, Peralta-Rodríguez J, Pérez-Rentería C, et al. Urban and semi-urban mosquitoes of Mexico City: a risk for endemic mosquito-borne disease transmission. PLoS One. 2019;14:e0212987.

5. Jansen CC, Beebe NW. The dengue vector Aedes aegypti: what comes next. Microbes Infect. 2010;12:272-279.

6. Li Y, Kamara F, Zhou G, Puthiyakunnon S, Li C, Liu Y, et al. Urbanization increases Aedes albopictus larval habitats and accelerates mosquito development and survivorship. PLoS Negl Trop Dis. 2014;8:e3301.

7. Narro-Robles J, Gómez-Dantés H. El dengue en Mexico: un problema prioritario de salud publica. Salud Publica Mex. 1995;37:12-20.

8. Vázquez-Castellanos J, Canales-Muñoz J, Nápoles-Camacho, CastiIlo-Morán MA, Ureña-Carillo LE. Estudio del primer gran brote epidémico de dengue en Guadalajara, Jalisco, México, octubre de 1988. Rev Salud Jalisco. 2018;5:8-19.

9. Centro Nacional de Programas Preventivos y Control de Enfermedades [Internet]. Mexico: Guía metodológica para la vigilancia entomológica con ovitrampas; 2017

10. Fay RW, Eliason DA. A preferred oviposition site as a surveillance method for Aedes aegypti. Mosq News. 1966;26:531-535

11. Chaverri LG, Dillenbeck C, Lewis D, Rivera C, Romero LM, Chaves LF. Mosquito species (Diptera: Culicidae) diversity from ovitraps in a Mesoamerican tropical rainforest. J Med Entomol. 2018;55:646-653.

12. Ortega-Morales Al, Moreno-García M, González-Acosta C, Correa-Morales F. Mosquito surveillance in Mexico: the use of ovitraps for Aedes aegypti, Ae. albopictus, and non-target species. Florida Entomol. 2018;101:623-627.

13. Ibánez-Bernal S, Martínez-Campos C. Clave para la identificación de larvas de mosquitos comunes en las áreas urbanas y suburbanas de la República Mexicana (Diptera: Culicidae). Folia Entomol Mex. 1994;92:43-73.
14. Darsie RF, Ward RA. Identification and geographical distribution of the mosquitoes of North America, North of Mexico. USA: University Press of Florida; 2005.

15. Cheong WH. Preferred Aedes aegypti larval habitats in urban areas. Bull World Health Organ. 1967;36:586-589.

16. Candelario-Mejía, G Rodríguez-Rivas A, Muñoz-Urias A, González-Carcamo J, Candelario-Valencia, A Mosso-González C, et al. Estudio observacional de la fluctuación espacial y temporal de Aedes aegypti en el área metropolitana de Guadalajara, México. Rev Med MD. 2014;6:6-12.

17. Villegas-Trejo A, Che-Mendoza A, González-Fernández M, Guillermo-May G, González-Bejarano H, Dzul-Manzanilla F, et al. Control enfocado de Aedes aegypti en localidades de alto riesgo de transmisión de dengue en Morelos, México. Salud Publica Mex. 2011;53:141-151.

18. Marquetti MC, Suárez S, Bisset J, Leyva M. Reporte de hábitats utilizados por Aedes aegypti en Ciudad de La Habana, Cuba. Rev Cubana Med Trop. 2005;57:159-161.

19. De la Cruz-Francisco V, Veda-Moreno DI, Valdés-Murillo A. Aspectos ecológicos de la incidencia larval de mosquitos (Diptera: Culicidae) en Tuxpan, Veracruz, México. Rev Colomb Entomol. 2012;38:128-133.

20. Manrique-Saide P, Arisqueta-Chable C, Geded-Moreno E, Herrera-Bojórquez J, Valentín UC, Chable-Santos J, et al. An assessment of the importance of subsurface catch basins for Aedes aegypti adult production during the dry season in a neighborhood of Merida, Mexico. J Am Mosq Control Assoc. 2013;29:164-167.

21. Arana-Guardia R, Baak-Baak CM, Lorono-Pino MA, Machain-Williams C Beaty BJ, Eisen L, et al. Stormwater drains and catch basins as sources for production of Aedes aegypti and Culex quinquefasciatus. Acta Trop. 2014;134:33-42.

22. Unlu I, Faraii A, Indelicato N, Fonseca DM. The hidden world of Asian tiger mosquitoes: immature Aedes albopictus (Skuse) dominate in rainwater corrugated extension spouts. Trans R Soc Trop Med Hyg. 2014;108:699-705.

23. Hopp MJ, Foley JA. Global-scale relationships between climate and the dengue fever vector, Aedes Aegypti. Clim Change. 2001;48:441-463.

24. Kraemer MUG, Sinka ME, Duda KA, Mylne AQN, Shearer FM, Barker CM, et al. The global distribution of the arbovirus vectors Aedes aegypti and Ae. albopictus. Elife. 2015;4:e08347.

25. Ruiz-López F, González-Mazo A, Vélez-Mira A, Gómez GF, Zuleta L, Vélez-Bernal ID. Presencia de Aedes (Stegomyia) aegypti (Linnaeus, 1762) y su infección natural con el virus del dengue en alturas no registradas para Colombia. Biomedica. 2016;36:303-308.

26. Castillo-Quino R, Vallejo-Castro E, Camacho-Aliaga A V, Quiñones-López A, Canelas-Urey HI. Adaptación del mosquito Aedes aegypti a 2550 m s.n.m. Cochabamba, Bolivia. Gac Med Bol. 2018:41:24-30.

27. Lozano-Fuentes S, Hayden MH, Welsh-Rodriguez C, Ochoa-Martínez C, Tapia-Santos B, Kobylinski KC, et al. The dengue virus mosquito vector Aedes aegypti at high elevation in México. Am J Trop Med Hyg. 2012;87:902-909.

28. Arellano-Carbajal G, Chaparro-Arias F. Alternativa de suministro de agua potable a la delegación Gustavo A. Madero. [Graduation thesis]. Mexico: Instituto Politecnico Nacional; 2004.

29. Procuraduría Ambiental y del Ordenamiento Territorial del Distrito Federal [Internet]. Mexico: Distribución espacial de los asentamientos humanos irregulares ubicados en el suelo de conservación en relación con el proyecto del Programa General de Ordenamiento Ecológico y Zonas de Valor Ambiental del Distrito Federal; 2011

30. Fajardo-Dolci G, Meljem-Moctezuma J, Vicente-González E, Venegas-Páez F, Mazón-González B, Aguirre-Gas H. El dengue en México. Conocer para mejorar la calidad de la atención. Rev Med Inst Mex Seguro Soc. 2012;50:631-639. 